\title{
Periplasmic maltose- and glucose-binding protein activities in cell-free extracts of Thermotoga maritima
}

\author{
Dhaval Nanavati, Kenneth M. Noll and Antonio H. Romano
}

Department of Molecular and Cell Biology, University of Connecticut, Storrs, CT 06269-3125, USA
Author for correspondence: Kenneth M. Noll. Tel: +1 860486 4688. Fax: +1 8604864331. e-mail:noll@uconnvm.uconn.edu

In this study, high-affinity maltose- and glucose-binding activities in cell-free extracts of Thermotoga maritima were detected; these activities were distinct and specific. At the gross level, the expression of binding-protein activities was repressed by growth of $T$. maritima in the presence of the cognate sugar. Growth of the organism in the presence of maltose reduced maltose-binding activity but not glucose-binding activity, while growth in the presence of glucose reduced glucose-binding activity but not maltose-binding activity. In competition assays, these binding activities showed distinct patterns of substrate specificity: whereas the maltose-binding activity showed specificity for $\alpha$-linked glucosides, the glucose-binding activity showed a broader specificity. All maltose- and glucose-binding activity was found in the supernatant retrieved following centrifugation $(100000 \mathrm{~g})$ of the cell-free extracts prepared by French-pressure-cell treatment; no activity was found in an octyl-glucoside-treated extract of the membrane fraction. The maltosebinding-protein activity was recovered from the periplasmic fraction by selective release of the periplasmic contents of $T$. maritima cells using a newly developed freeze-thaw procedure. Annotation of the complete genome sequence of $T$. maritima suggests that there may be at least two maltosebinding proteins, MalE1 and MalE2, encoded in the genome. The maltosebinding activity corresponded to a protein of $43 \mathrm{kDa}$, which was consistent in size with either of the putative proteins. These data demonstrate that the hyperthermophilic bacterium $\boldsymbol{T}$. maritima possesses separate maltose- and glucose-binding-protein activities that are freely soluble in its periplasm, in contrast to the membrane-bound sugar-binding proteins found in archaeal hyperthermophiles.

Keywords: hyperthermophile, sugar transport, ABC transporters, transporter evolution

\section{INTRODUCTION}

The suite of substrate transporters expressed by a cell dictates how readily an organism can use available nutrients in its environment. Consequently, transporters are important elements in the evolution of cellular metabolism and may dictate the competitive success of an organism in a given ecosystem. It is not surprising that among sequenced genomes transporters comprise a relatively large fraction of the coding capacity of these genomes (Paulsen et al., 2000). Insights into the evolution of this important process can be gained by

Abbreviation: $A B C$, ATP-binding cassette. examining transporter functions among organisms that span the phylogenetic spectrum. Thus, we report here an examination of sugar-binding activities by the hyperthermophilic bacterium Thermotoga maritima.

Transporters can be classified into five groups based upon how energy is expended by an organism to effect concentrative uptake of substrates (Albers et al., 2001). Two of these groups, the secondary transporters and the ATP-linked primary transporters, are ubiquitous among sequenced prokaryotic genomes (Paulsen et al., 2000), suggesting that they were among the first transport systems to evolve. Secondary transporters use electrochemical energy stored in transmembrane ion gradients to drive solute translocation. Primary transporters 
use the energy of ATP hydrolysis to take up solutes and are called ATP-binding cassette (ABC) transporters. $\mathrm{ABC}$ transporters utilize periplasmic, high-affinity binding proteins to bring the substrate to the transmembrane components, which effect transport driven by hydrolysis of ATP catalysed by associated cytoplasmic ATPbinding proteins. Substrate-binding proteins differ among micro-organisms, in that some are soluble in the periplasm while others, particularly among Grampositive organisms, are tethered to the cell membrane (Jones et al., 2000 ; Paulsen, 1999). Recently, membraneassociated sugar-binding proteins were found in the archaeal species Thermococcus litoralis, Pyrococcus furiosus and Sulfolobus solfataricus (Elferink et al., 2001; Koning et al., 2001a, b; Xavier et al., 1996). Given this distribution of $\mathrm{ABC}$ transporters, it is of interest to examine their distribution and function among representatives of evolutionarily important bacteria such as T. maritima. On the basis of comparisons among $16 \mathrm{~S}$ rRNA gene sequences, the order Thermotogales represents a bacterial lineage that may resemble the earliest ancestors of the Bacteria (Fitz-Gibbon \& House, 1999; Pace, 1997). However, other measures of the evolution of protein-encoding sequences place T. maritima and its related species higher in the bacterial lineage (Brochier \& Philippe, 2002; Brown \& Doolittle, 1997; Gupta, 1998; Klenk et al., 1999). The precise placement of this lineage notwithstanding, the order Thermotogales clearly represents an evolutionarily and physiologically important group of organisms. Evidence suggests that this lineage has inherited DNA from archaea through lateral gene transfer (Nelson et al., 1999; Nesbo et al., 2001) and that some of these inherited genes encode putative transporters (Nelson et al., 2001). Thus, we set out to examine sugar transporters in T. maritima, to better understand the constraints on such genetic exchanges and what impact they have had on the evolution of this organism.

We have previously shown that Thermotoga neapolitana, a close relative of $T$. maritima, does not have phosphoenolpyruvate: sugar phosphotransferase (PTS) transporters for glucose, fructose, galactose or lactose. Likewise, others have shown that the genome sequence of T. maritima has no ORFs identifiable as PTSencoding genes (Galperin et al., 1996, 1997; Nelson et al., 1999). Since the annotation of the T. maritima genome sequence has suggested several ABC-type transporters may be encoded there, we set out to measure periplasmic sugar-binding activities in this organism. Here, we provide the first description of a method to selectively release the periplasmic contents of $T$. maritima, a method that may be used to examine the periplasmic functions of this organism. We used this method to demonstrate that T. maritima has both maltose- and glucose-binding activities and that the proteins responsible for these activities are located in its periplasm as soluble proteins. Furthermore, we have shown that the expression of these binding activities by $T$. maritima is differentially regulated in response to the growth substrate used.

\section{METHODS}

Organism and growth conditions. T. maritima $\mathrm{MSB}^{\mathrm{T}}$ (DSM $3109^{\mathrm{T}}$ ) was obtained from the Deutsche Sammlung von Mikroorganismen und Zellkulturen, Braunschweig, Germany. Cells were grown on a modified basal defined medium (Childers et al., 1992) that contained $\left(1^{-1}\right) 20 \mathrm{~g} \mathrm{NaCl}, 4 \cdot 8 \mathrm{~g}$ HEPES, $0.5 \mathrm{~g}$ cysteine, $0.25 \mathrm{~g} \mathrm{NH}_{4} \mathrm{Cl}, 0.05 \mathrm{~g} \mathrm{CaCl}_{2}, 0.05 \mathrm{~g}$ $\mathrm{K}_{2} \mathrm{HPO}_{4}, 2 \mathrm{~g} \mathrm{KCl}, 0 \cdot 1 \mathrm{~g} \quad \mathrm{MgSO}_{4}, 2.5 \mathrm{~g} \quad \mathrm{Na}_{2} \mathrm{~S}_{2} \mathrm{O}_{3}, 7 \mu \mathrm{g}$ $\mathrm{FeSO}_{4} .7 \mathrm{H}_{2} \mathrm{O}$ and $1 \mathrm{ml}$ of a vitamin solution containing $\left(1^{-1}\right)$ $10 \mathrm{mg}$ pyridoxine $/ \mathrm{HCl}, 5 \mathrm{mg}$ calcium pantothenate, $5 \mathrm{mg}$ nicotinic acid, $5 \mathrm{mg}$ riboflavin, $5 \mathrm{mg}$ thiamin $/ \mathrm{HCl}, 5 \mathrm{mg}$ thioctic acid, $2 \mathrm{mg}$ biotin, $2 \mathrm{mg}$ folic acid and $0.1 \mathrm{mg}$ cyanocobalamin. The medium was dispensed into serum bottles and de-gassed by heating in a steam cabinet until the resazurin indicator was colourless. The bottles were closed with butylrubber stoppers with aluminium crimp seals and flushed with oxygen-free nitrogen for $10 \mathrm{~min}$ before sterilization by autoclaving at $121^{\circ} \mathrm{C}$ for $30 \mathrm{~min}$. Sugars used as the carbon and energy source were sterilized separately by filtration of anoxic solutions before addition to the medium at a final concentration of $5 \mathrm{~g} \mathrm{l}^{-1}$. When yeast extract was used in the medium instead of sugars it was added to the medium, before autoclaving, at a concentration of $1 \mathrm{~g}^{-1}$.

Cells were grown at $77^{\circ} \mathrm{C}$ under strictly anaerobic conditions. Typically, $15 \mathrm{ml}$ of an overnight culture were transferred to $300 \mathrm{ml}$ fresh medium and grown to late-exponential phase (24 h for glucose, $12 \mathrm{~h}$ for maltose). For harvesting of the cells, cultures were cooled to $4{ }^{\circ} \mathrm{C}$ overnight, centrifuged at $4{ }^{\circ} \mathrm{C}$ at $6000 \mathrm{~g}$ for $20 \mathrm{~min}$, resuspended in a wash buffer $(30 \mathrm{mM} \mathrm{KCl}$, $2 \mathrm{mM} \mathrm{MgSO}_{4}, 40 \mathrm{mM} \mathrm{KH}_{2} \mathrm{PO}_{4}, \mathrm{pH} 7 \cdot 0$ ) and then centrifuged again at $6000 \mathrm{~g}$. The resulting cell pellet was stored at $-20^{\circ} \mathrm{C}$ for further processing.

Preparation of cell extracts. Cell extracts of T. maritima were prepared by two methods. (A) Cells harvested and washed as above were resuspended in $7-10 \mathrm{ml}$ of $50 \mathrm{mM}$ Tris/ $\mathrm{HCl}$ buffer (pH 7.5) containing $1 \mathrm{mM} \mathrm{MgSO}_{4}$ and $1 \mathrm{mM}$ PMSF, then ruptured by one passage through a French pressure cell (Aminco) at 20000 p.s.i. (137.8 MPa). Cell debris and membrane fragments were separated by centrifugation at $100000 \mathrm{~g}$ for $1 \mathrm{~h}$ at $4{ }^{\circ} \mathrm{C}$. The supernatant was saved as the 'soluble fraction'. To extract membrane proteins, the pellet was washed with $5 \mathrm{ml}$ of $50 \mathrm{mM}$ Tris/ $\mathrm{HCl}(\mathrm{pH} 7 \cdot 5)$ containing $1 \mathrm{mM} \mathrm{MgSO}$, centrifuged again at $100000 \mathrm{~g}$, then extracted with $5 \mathrm{ml}$ of $1 \%$ octyl glucoside in $50 \mathrm{mM}$ Tris $/ \mathrm{HCl}(\mathrm{pH} 7 \cdot 5)$ by gentle stirring overnight at $5{ }^{\circ} \mathrm{C}$. (B) Where indicated, cells were disrupted by suspension in $0 \cdot 2 \%$ Triton X-100 in $50 \mathrm{mM}$ Tris/ $\mathrm{HCl}(\mathrm{pH} 7.5)$ containing $1 \mathrm{mM}$ PMSF. The resulting extract was clarified by centrifugation at $10000 \mathrm{~g}$. Protein content in all extracts was determined by the method of Bradford (1976) (Sambrook et al., 1989).

Fractionation of cells to release periplasmic and cytoplasmic proteins. A freeze-thaw procedure was used to selectively release periplasmic proteins from T. maritima. Frozen cell pellets that had been maintained at $-20^{\circ} \mathrm{C}$ for $48 \mathrm{~h}$ were suspended in $50 \mathrm{mM} \mathrm{MgCl}_{2}$ in $50 \mathrm{mM}$ Tris $/ \mathrm{HCl}(\mathrm{pH} 7.5)$ at a cell density of $140 \mathrm{mg}^{\mathrm{wet}} \mathrm{wt} \mathrm{ml} \mathrm{m}^{-1}$ and stirred for $30 \mathrm{~min}$ at room temperature. The suspension was centrifuged at $8000 \mathrm{~g}$ for $10 \mathrm{~min}$, then washed with distilled water by stirring for $1 \mathrm{~h}$ at room temperature and centrifuged again. The pelleted cells were then treated with $0 \cdot 2 \%$ Triton X-100 in $50 \mathrm{mM}$ Tris $/ \mathrm{HCl}$ $(\mathrm{pH} 7 \cdot 5)$. Maltose-binding activity and enolase activity were measured at each step.

Determination of maltose and glucose binding. The procedure of Richarme \& Kepes (1983) was followed, whereby the sugar-binding protein-ligand interaction with ammonium 
sulfate allows adsorption to cellulose ester filters. Glass test tubes $(12 \times 100 \mathrm{~mm})$ containing $50 \mu \mathrm{l}$ of the extract containing binding protein and $10 \mu \mathrm{l}$ of water or another specified addition were pre-heated in a heating block at $55^{\circ} \mathrm{C}$ (or other specified temperature) for $30 \mathrm{~s}$, then $10 \mu \mathrm{l}$ of $7 \mu \mathrm{M} \alpha$-D-[U$\left.{ }^{14} \mathrm{C}\right]$ maltose $\left(594 \mathrm{mCi} \mathrm{mmol}^{-1}, 21.98 \mathrm{GBq} \mathrm{mmol}^{-1} ; \mathrm{ICN}\right)$ or D$\left[{ }^{14} \mathrm{C}\right]$ glucose $\left(210 \mathrm{mCi} \mathrm{mmol}^{-1}, 7 \cdot 7 \mathrm{GBq} \mathrm{mmol}^{-1}\right.$; ICN) was added rapidly to the samples with a micropipette. After an additional $30 \mathrm{~s}$ (or other specified time) at $55^{\circ} \mathrm{C}, 2 \mathrm{ml}$ of icecold, saturated $\left(\mathrm{NH}_{4}\right)_{2} \mathrm{SO}_{4}$ in $50 \mathrm{mM}$ Tris $/ \mathrm{HCl}(\mathrm{pH} 7 \cdot 5)$ was added to the samples and the tubes were transferred to an ice bath for at least $10 \mathrm{~min}$. The contents of the tubes were then filtered through Whatman cellulose nitrate membrane filters ( $25 \mathrm{~mm}, 0.45 \mu \mathrm{m}$ porosity) and washed with an additional $2 \mathrm{ml}$ of ice-cold, saturated $\left(\mathrm{NH}_{4}\right)_{2} \mathrm{SO}_{4}$ in buffer. The filters were then placed in scintillation fluid (Optifluor; Packard) for counting in a Beckman LS 3801 liquid scintillation spectrometer. Apparent binding constants of approximately $0 \cdot 3 \mu \mathrm{M}$ were determined for both glucose and maltose using the cell extracts of T. maritima. As described above, routine binding assays used a saturating concentration of these sugars (over threefold excess).

Enolase assay. Enolase (EC 4.2.1.11) activity was measured at $77^{\circ} \mathrm{C}$ by monitoring the formation of phosphoenolpyruvate (PEP) spectrophotometrically at $240 \mathrm{~nm}$. The extinction coefficient of PEP was determined by us to be $1.4 \mathrm{mM}^{-1} \mathrm{~cm}^{-1}$ in $100 \mathrm{mM}$ Tris $/ \mathrm{HCl}(\mathrm{pH} 8 \cdot 0)$. The assay mixture contained $100 \mathrm{mM}$ Tris/HCl (pH 8.0), $5 \mathrm{mM}$ 2-phosphoglycerate, $2 \mathrm{mM}$ $\mathrm{MgSO}_{4}$ and 50-100 $\mu \mathrm{l}$ of cell extract in a final volume of $1 \mathrm{ml}$.

SDS-PAGE of maltose-binding protein and detection of binding activity in a non-denaturing gel. Periplasmic protein fractions prepared by the freeze-thaw procedure described above were concentrated by ultrafiltration (10000 Da cut-off). Fifty microlitres of the periplasmic extract was incubated with $10 \mu \mathrm{l}$ of $7 \mu \mathrm{M} \alpha-\mathrm{D}-\left[\mathrm{U}_{-}{ }^{14} \mathrm{C}\right]$ maltose $\left(594 \mathrm{mCi} \mathrm{mmol}^{-1}\right.$, $21.98 \mathrm{GBq} \mathrm{mmol}^{-1}$ ) and $10 \mu \mathrm{l} \mathrm{of}$ water at $50{ }^{\circ} \mathrm{C}$ for $30 \mathrm{~s}$ to allow binding, then an equal volume of $2 \times$ loading dye was added to the assay. An aliquot of this mixture $(120 \mu \mathrm{l})$ was loaded onto a non-denaturing $10 \%$ polyacrylamide gel, prepared as described by Sambrook et al. (1989). Adjacent lanes were loaded with $50 \mu \mathrm{l}$ of the periplasmic extract. After electrophoresis for $12 \mathrm{~h}$ at room temperature, the gel was washed with distilled water to remove any unbound radioactive sugar. The lane loaded with the radioactive binding mixture was cut into 0.25 or $0.5 \mathrm{~cm}$ strips, which were individually transferred to scintillation fluid for determination of radioactivity. One adjacent lane of the gel was stained with $0 \cdot 1 \%$ Coomassie blue and destained with an acetic acid/water/methanol mixture $(1: 3: 6)$ to visualize the protein bands. The other adjacent lane was cut at the location corresponding to radioactivity detected in the band loaded with the binding mixture, and the excised piece of gel was extracted with $0.1 \mathrm{ml}$ of $0.5 \%$ SDS in $25 \mathrm{mM}$ Tris $/ \mathrm{HCl}$ for $24 \mathrm{~h}$ at $4{ }^{\circ} \mathrm{C}$. An aliquot of this eluate $(50 \mu \mathrm{l})$ was loaded onto a $12 \%$ polyacrylamide denaturing gel and subjected to electrophoresis.

\section{RESULTS AND DISCUSSION}

\section{Maltose and glucose binding in cell-free extracts of $T$. maritima}

Extracts of cells grown on maltose or glucose and disrupted by French-pressure-cell treatment (method A) showed binding of both $\left[{ }^{14} \mathrm{C}\right]$ maltose and $\left[{ }^{14} \mathrm{C}\right]$ glucose. Separation of the soluble and particulate fractions of the French-pressure-cell extracts by ultracentrifugation at
$100000 \mathrm{~g}$ and subsequent extraction of the particulate fraction by octyl glucoside showed that maltose- and glucose-binding activities were predominantly associated with the soluble fraction $-\left[{ }^{14} \mathrm{C}\right]$ maltose and $\left[{ }^{14} \mathrm{C}\right]$ glucose were bound by the soluble fraction at 53 and $20 \mathrm{nmol}$ sugar $(\mathrm{mg} \text { protein })^{-1}$, respectively, whereas they were bound by the membrane fraction at 4 and $1 \mathrm{nmol}$ sugar (mg protein $)^{-1}$, respectively. This is in contrast to the maltose-binding protein of the hyperthermophilic archaeon $T$. litoralis, which has been shown to be membrane-associated (Xavier et al., 1996). It should be noted that cell extracts for $\left[{ }^{14} \mathrm{C}\right]$ maltosebinding experiments were prepared from glucose-grown cells while extracts used for $\left[{ }^{14} \mathrm{C}\right]$ glucose-binding experiments were prepared from maltose-grown cells. As noted below, binding activities were lowest in cells grown on the cognate sugar.

These maltose- and glucose-binding activities appear to be distinct, since the patterns of inhibition of isotopic sugar binding to protein by non-isotopic sugars indicated different patterns of specificity. A comparison of the sugar-binding specificities as determined by the inhibition of isotopic sugar binding is shown in Table 1 . Maltose binding appeared to be strongly dependent on the $\alpha$-glycosidic linkage, since the $\alpha$-glycosides trehalose and methyl $\alpha$-D-glucopyranoside significantly inhibited maltose binding while the $\beta$-galactosides cellobiose and lactose had little or no effect on this binding. The monosaccharides tested showed low inhibition of maltose binding, with D-glucose, the constituent monosaccharide of maltose, showing a greater effect than Dgalactose. Glucose binding showed a broader specificity, with $\alpha$ - or $\beta$-linked disaccharides containing a glucose moiety all showing a degree of binding inhibition. $\mathrm{D}^{-}$ Galactose, a D-glucose epimer, showed the least inhibition of glucose binding.

\section{Effect of temperature on maltose and glucose binding}

We examined the effect of temperature on maltose and glucose binding using Triton X-100 cell extracts. Binding of these sugars showed apparent optimal temperatures of $60{ }^{\circ} \mathrm{C}$ for maltose and $50{ }^{\circ} \mathrm{C}$ for glucose, though there was significant binding of both sugars at $0{ }^{\circ} \mathrm{C}(53$ and $47 \%$ of the maximum for maltose and glucose, respectively). Sugar binding at $78^{\circ} \mathrm{C}$, the optimal growth temperature of T. maritima, was 79 and $72 \%$ of the maximum for maltose and glucose, respectively. The decrease in binding activity at higher temperatures might be due to the activation of proteases in the cell extracts. A purified recombinant maltose-binding protein from T. maritima expressed in Escherichia coli was thermally stable to over $105^{\circ} \mathrm{C}$ (Wassenberg et al., 2000).

\section{Release of maltose-binding activity from the periplasm}

With the objective of further localizing the sugar-binding cellular constituent(s) of $T$. maritima, we set about developing a method to release the presumed binding 
Table 1. Inhibition of $\left[{ }^{14} \mathrm{C}\right]$ maltose and $\left[{ }^{14} \mathrm{C}\right]$ glucose binding by other sugars

$\left[{ }^{14} \mathrm{C}\right]$ Maltose- and $\left[{ }^{14} \mathrm{C}\right]$ glucose-binding assays were carried out with extracts of $T$. maritima cells that had been grown on glucose or maltose, respectively, which were ruptured by treatment with $0 \cdot 2 \%$ Triton X-100. The binding activities of the respective extracts were 64 nmol maltose $(\mathrm{mg}$ protein $)^{-1}$ and $19 \mathrm{nmol}$ glucose $(\mathrm{mg} \text { protein })^{-1}$. Competing sugars were present at a final concentration of $0.14 \mathrm{mM}$.

\begin{tabular}{|c|c|c|}
\hline \multirow[t]{2}{*}{ Competing sugar } & \multicolumn{2}{|c|}{ Percentage inhibition of binding } \\
\hline & {$\left[{ }^{14} \mathrm{C}\right]$ Maltose } & {$\left[{ }^{14} \mathrm{C}\right]$ Glucose } \\
\hline Maltose [ $\alpha$-D-glucopyranosyl-( $1 \rightarrow 4)$-D-glucose $]$ & 94 & 73 \\
\hline D-Glucose & 20 & 93 \\
\hline Trehalose [ $\alpha$-D-glucopyranosyl $\alpha$-D-glucose] & 90 & 28 \\
\hline Cellobiose [ $\beta$-D-glucopyranosyl- $(1 \rightarrow 4)$-D-glucose $]$ & 20 & 50 \\
\hline D-Galactose & 0 & 0 \\
\hline Lactose $[\beta$-D-galactopyranosyl- $(1 \rightarrow 4)$-D-glucose $]$ & 0 & 73 \\
\hline Methyl $\alpha$-D-glucopyranoside & 83 & 75 \\
\hline
\end{tabular}

Table 2. $\left[{ }^{14} \mathrm{C}\right]$ Maltose- and $\left[{ }^{14} \mathrm{C}\right]$ glucose-binding activities, and enolase activity in cell fractions

Cells were fractionated as described in Methods. Wet cell pellets $(0 \cdot 1 \mathrm{~g})$ were frozen for $48 \mathrm{~h}$ at $-20^{\circ} \mathrm{C}$, then extracted with $1 \mathrm{ml}$ of $50 \mathrm{mM} \mathrm{MgCl}_{2}$ in $50 \mathrm{mM}$ Tris/ $\mathrm{HCl}(\mathrm{pH} \mathrm{7.5)}$, washed with $1 \mathrm{ml}$ distilled water and lysed with a solution of $1 \mathrm{ml}$ of $0 \cdot 2 \%$ Triton X-100 in buffer.

\begin{tabular}{|c|c|c|c|c|}
\hline \multirow[t]{2}{*}{ Fraction } & \multicolumn{2}{|c|}{$\left[{ }^{14} \mathrm{C}\right]$ Maltose bound } & \multicolumn{2}{|c|}{ Enolase activity } \\
\hline & nmol & $\begin{array}{c}\text { Percentage } \\
\text { of total }\end{array}$ & nmol & $\begin{array}{c}\text { Percentage } \\
\text { of total }\end{array}$ \\
\hline $\mathrm{MgCl}_{2} /$ buffer extract of frozen-thawed cells & 1787 & 76 & 9 & 7 \\
\hline Water wash & 309 & 13 & 4 & 3 \\
\hline Triton X-100 extract of residual cells & 261 & 11 & 118 & 90 \\
\hline Total & 2357 & & 131 & \\
\hline \multirow[t]{2}{*}{ Fraction } & \multicolumn{2}{|c|}{$\left[{ }^{14} \mathrm{C}\right]$ Glucose bound } & \multicolumn{2}{|c|}{ Enolase activity } \\
\hline & nmol & $\begin{array}{c}\text { Percentage } \\
\text { of total }\end{array}$ & nmol & $\begin{array}{c}\text { Percentage } \\
\text { of total }\end{array}$ \\
\hline $\mathrm{MgCl}_{2} /$ buffer extract of frozen-thawed cells & 510 & 72 & 2 & 7 \\
\hline Water wash & 82 & 12 & 2 & 7 \\
\hline Triton X-100 extract of residual cells & 117 & 17 & 27 & 87 \\
\hline Total & 709 & & 31 & \\
\hline
\end{tabular}

proteins from cells of this organism. Having found that the binding activity was not membrane-bound (see above), we investigated a number of osmotic-shock procedures that have been successful in releasing sugarbinding proteins from the periplasm of a number of Gram-negative bacteria. The procedure we found to be most useful for $T$. maritima was a freeze-thaw procedure involving extraction of frozen cells with $50 \mathrm{mM}$ $\mathrm{MgCl}_{2}$ in Tris/ $\mathrm{HCl}$ ( $\mathrm{pH} 7 \cdot 5$ ) (see Methods). The results of assays of $\left[{ }^{14} \mathrm{C}\right]$ maltose- and $\left[{ }^{14} \mathrm{C}\right]$ glucose-binding activities carried out on fractions obtained from this procedure are shown in Table 2. Enolase activity was also measured in each fraction to determine the levels of contamination with cytoplasmic enzymes within these fractions. The freeze-thaw $/ \mathrm{MgCl}_{2}$ buffer extraction combined with the subsequent distilled-water wash recovered more than $84 \%$ of the maltose- or glucosebinding activities and only $10-14 \%$ of the enolase activity. By comparison, the Triton X-100 extract of the residual cells contained $87-90 \%$ of the total enolase 
Table 3. Effect of carbon source on $\left[{ }^{14} \mathrm{C}\right]$ maltose- and $\left[{ }^{14} \mathrm{C}\right]$ glucose-binding activity

Cells were grown in basal defined medium containing $0.5 \%$ of the specified carbon source to late-exponential phase through two growth cycles, then harvested by centrifugation, washed and resuspended in $50 \mathrm{mM}$ Tris/ $\mathrm{HCl}$ buffer. The cells were finally disrupted by treatment with $0 \cdot 2 \%$ Triton X-100.

\begin{tabular}{|lcc|}
\hline Carbon source & \multicolumn{2}{c|}{ Sugar bound $\left[\mathrm{nmol}(\mathrm{mg} \text { protein })^{-1}\right]$} \\
\cline { 2 - 3 } & {$\left[{ }^{14} \mathrm{C}\right]$ Maltose } & {$\left[{ }^{14} \mathrm{C}\right]$ Glucose } \\
\hline Yeast extract & 64 & 24 \\
Starch & 25 & 14 \\
Maltose & 6 & 19 \\
Glucose & 63 & 3 \\
Lactose & 16 & 4 \\
\hline
\end{tabular}

activity and only $11-17 \%$ of the total maltose-binding activity. Thus, the sugar-binding proteins are soluble in the periplasmic fraction of cells of $T$. maritima.

\section{Effect of growth medium on maltose- and glucose- binding activity}

Our intent was to grow T. maritima on a number of different carbon sources, including carbohydrates and other classes of compounds, so that we might observe patterns of induction or repression of binding-protein synthesis. However, growth of T. maritima is obligately dependent on the fermentation of sugars, and we were not able to grow the organism on such complex lowcarbohydrate substrates as peptone or on fermentation intermediates such as pyruvate. The closest we could come to a complex organic substrate that supported growth of the organism was yeast extract, but this material contains significant amounts of the yeast storage disaccharide trehalose. Indeed, Xavier et al. (1996) found that trehalose was an inducer and a substrate of the maltose-transport system of Thermococcus litoralis.

Results shown in Table 3 show that maltose- and glucose-binding activities were highest in extracts from T. maritima cells grown with yeast extract added as carbon and energy source. Sugar-binding activity was lowest in extracts of cells grown in the presence of the cognate sugar. Thus, growth of $T$. maritima in the presence of maltose reduced maltose-binding activity to a much greater extent than it reduced glucose-binding activity, while growth in the presence of glucose greatly reduced glucose-binding activity but not maltose-binding activity. Growth of T. maritima on either starch or lactose gave higher maltose-binding activity than glucose-binding activity.

At the gross level, these results indicate that the binding proteins are repressed by growth of $T$. maritima in the presence of the cognate sugar. The high binding activities for both sugars in yeast-extract-grown cells might result from the lower concentrations of the sugars in this substrate and their rapid utilization during growth of the organism. Similarly, the observation that binding activities for both maltose and glucose were higher in starch-grown cells than in cells grown on either of the cognate sugars alone might be explained by the rapid utilization with little or no accumulation of maltose or glucose resulting from starch breakdown. Such a regulatory system for binding-protein synthesis, based on repression, would be advantageous for $T$. maritima, a marine organism dependent on carbohydrates that lives in an environment with a low carbohydrate concentration. Enhanced synthesis of the high-affinity binding proteins would allow scavenging of substrate at very low concentrations, while at higher substrate concentrations energy for synthesis of excess binding protein would be conserved.

There have been reports of repression-based control of binding-protein-associated carbohydrate-transport systems in other bacteria. For example, E. coli grown at micromolar glucose concentrations in carbon-limited chemostats showed elevated levels of both the methyl galactoside $(\mathrm{Mgl})$ system, an $\mathrm{ABC}$ transporter that recognizes glucose with high-affinity and which may in fact be primarily a glucose transporter, and the maltose system. Both systems were strongly repressed when cells of E. coli were growing exponentially in millimolar glucose concentrations (Death \& Ferenci, 1993, 1994).

Our results do not allow any conclusions regarding the inducibility of the binding proteins, since it has not been possible to grow cells in the absence of carbohydrates. It is possible that endogenous inducer accumulation occurs at very low carbohydrate concentrations as occurs in carbon-limited E. coli (Death \& Ferenci, 1994).

The annotated T. maritima genome sequence shows a large number of $\mathrm{ABC}$ carbohydrate transporters (Nelson et al., 1999; Paulsen et al., 2000). The low carbohydrate concentrations in the natural habitat of this bacterium were probably a factor in the selection for these highaffinity systems.

\section{Gel electrophoresis of the maltose-binding protein}

Two ORFs, TM1204 and TM1839, were annotated in the $T$. maritima genome sequence as genes encoding putative maltose-binding proteins (malE1 and malE2, respectively) (Nelson et al., 1999). No glucose-binding protein was identified as such in the annotation. Wassenberg et al. (2000) reported the cloning and expression of malE2 in E. coli and showed that this gene encodes a maltose-binding protein. We set out to determine whether malE1 or malE2 might encode the maltose-binding activity we detected in the cell-free extracts of $T$. maritima by identifying the maltosebinding protein in these extracts.

To identify the protein responsible for maltose binding, we incubated a periplasmic extract of T. maritima with $\left[{ }^{14} \mathrm{C}\right]$ maltose at $55^{\circ} \mathrm{C}$ to allow binding. We then resolved the proteins within this extract by PAGE under non- 
(a)

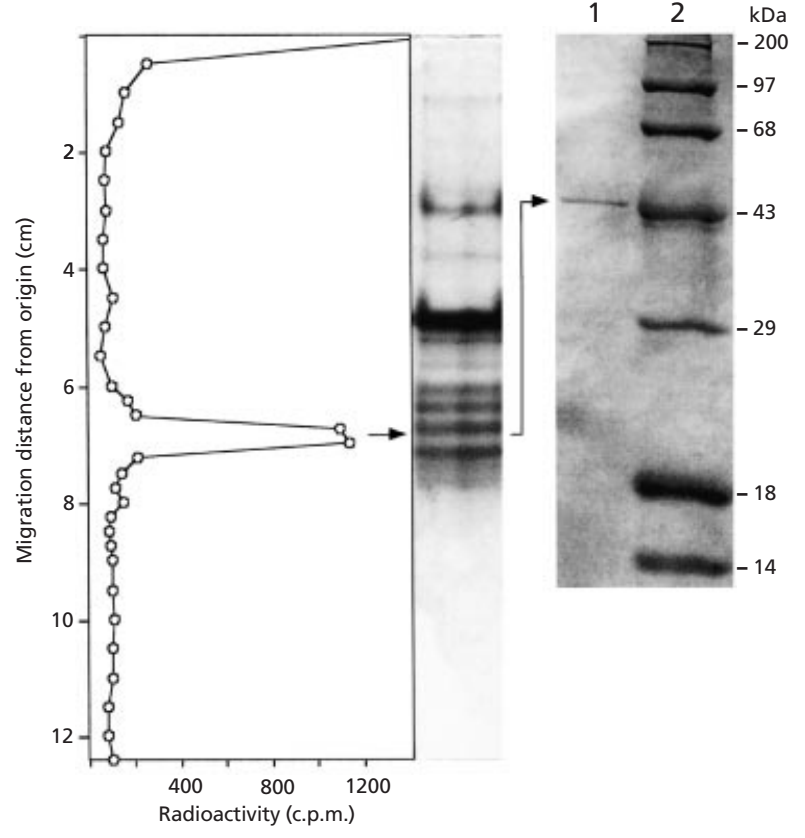

Fig. 1. Localization of the $\left[{ }^{14} \mathrm{C}\right]$ maltose-binding protein by gel electrophoresis. (a) Non-denaturing gel electrophoresis of periplasmic extract of glucose-grown cells after incubation at $55^{\circ} \mathrm{C}$ with $\left[{ }^{14} \mathrm{C}\right]$ maltose (see Methods). The arrow indicates the location of maximum radioactivity. (b) Lanes: 1, SDS-PAGE of gel slice cut from the position on the non-denaturing gel adjacent to the maximum radioactivity; 2, molecular mass markers.

denaturing conditions at room temperature (Fig. 1a). Apart from high radioactivity in the material that did not enter the gel, there was a single peak of radioactivity that corresponded to a protein band $6 \cdot 5-7 \cdot 0 \mathrm{~cm}$ from the origin of migration of the sample. A slice of the adjacent lane, which had been loaded with unlabelled cell extract, was cut at the position corresponding to the radioactive peak and eluted from the gel; the eluate was then subjected to SDS-PAGE. The results shown in Fig. 1(b) indicate that the eluate contained a principal band with an apparent molecular mass of $43 \mathrm{kDa}$. The size of this band is consistent with the predicted molecular masses of MalE1 and MalE2 (both $43 \mathrm{kDa}$ ). However, we found that this band apparently consisted of more than one protein, since $\mathrm{N}$-terminal amino acid sequence data suggested a mixture of proteins within the band. Periplasmic extracts provide very little binding protein and we found the activity of this protein is easily lost during subsequent purification steps; consequently, we were unable to purify this protein further. Although a single maltose-binding protein may simply be mixed with unrelated proteins, it may also be that more than one maltose-binding protein is present in cells of $T$. maritima. A similar situation was found in Sinorhizobium meliloti, where a genetic approach allowed investigators to determine that at least two trehalose-transporting ABC-transport systems are induced by trehalose
(Jensen et al., 2002). A genetic approach would help to differentiate the different binding proteins of $T$. maritima, but no genetic system allowing directed gene knockouts exists for this organism or any other hyperthermophile.

To identify the transporters used by T. maritima under different growth conditions, expression analyses of all of the binding-protein-encoding genes identified in the genome sequence of this organism during its growth on several different sugars would be very useful. To interpret these data, it will be necessary to assign functions to each of the putative binding proteins identified in the genome sequence through their biochemical characterizations. The combination of these data will provide a better understanding of how the evolutionarily important organism T. maritima controls sugar uptake with its large suite of transporters.

\section{ACKNOWLEDGEMENTS}

This work was supported by a grant from the US Department of Energy (DE-FG02-93ER20122).

\section{REFERENCES}

Albers, S.-V., Van de Vossenberg, J. L. C. M., Driessen, A. J. M. \& Konings, W. N. (2001). Bioenergetics and solute uptake under extreme conditions. Extremophiles 5, 285-294.

Bradford, M. M. (1976). A rapid and sensitive method for the quantitation of microgram quantities of protein utilizing the principle of protein-dye binding. Anal Biochem 72, 248-254.

Brochier, C. \& Philippe, H. (2002). Phylogeny : a non-hyperthermophilic ancestor for bacteria. Nature 417, 244.

Brown, J. R. \& Doolittle, W. F. (1997). Archaea and the prokaryote-to-eukaryote transition. Microbiol Mol Biol Rev 61, 456-502.

Childers, S. E., Vargas, M. \& Noll, K. M. (1992). Improved methods for cultivation of the extremely thermophilic bacterium Thermotoga neapolitana. Appl Environ Microbiol 58, 3949-3953.

Death, A. \& Ferenci, T. (1993). The importance of the bindingprotein-dependent $\mathrm{Mgl}$ system to the transport of glucose in Escherichia coli growing on low sugar concentrations. Res Microbiol 144, 529-537.

Death, A. \& Ferenci, T. (1994). Between feast and famine: endogenous inducer synthesis in the adaptation of Escherichia coli to growth with limiting carbohydrates. J Bacteriol 176, 5101-5107.

Elferink, M. G. L., Albers, S. V., Konings, W. N. \& Driessen, A. J. M. (2001). Sugar transport in Sulfolobus solfataricus is mediated by two families of binding protein-dependent ABC transporters. Mol Microbiol 39, 1494-1503.

Fitz-Gibbon, S. T. \& House, C. H. (1999). Whole genome-based phylogenetic analysis of free-living microorganisms. Nucleic Acids Res 27, 4218-4222.

Galperin, M. Y., Noll, K. M. \& Romano, A. H. (1996). The glucose transport system of the hyperthermophilic anaerobic bacterium Thermotoga neapolitana. Appl Environ Microbiol 62, 2915-2918.

Galperin, M. Y., Noll, K. M. \& Romano, A. H. (1997). Coregulation of $\beta$-galactoside uptake and hydrolysis by the hyperthermophilic bacterium Thermotoga neapolitana. Appl Environ Microbiol 63, 969-972. 
Gupta, R. S. (1998). Protein phylogenies and signature sequences: a reappraisal of evolutionary relationships among archaebacteria, eubacteria, and eukaryotes. Microbiol Mol Biol Rev 62, 14351491.

Jensen, J. B., Peters, N. K. \& Bhuvaneswari, T. V. (2002). Redundancy in periplasmic binding protein-dependent transport systems for trehalose, sucrose, and maltose in Sinorhizobium meliloti. J Bacteriol 184, 2978-2986.

Jones, C. R., Ray, M., Dawson, K. A. \& Strobel, H. J. (2000). Highaffinity maltose binding and transport by the thermophilic anaerobe Thermoanaerobacter ethanolicus 39E. Appl Environ Microbiol 66, 995-1000.

Klenk, H. P., Meier, T. D., Durovic, P., Schwass, V., Lottspeich, F., Dennis, P. P. \& Zillig, W. (1999). RNA polymerase of Aquifex pyrophilus: implications for the evolution of the bacterial rpoBC operon and extremely thermophilic bacteria. J Mol Evol 48, 528-541.

Koning, S. M., Konings, W. N. \& Driessen, A. J. M. (2001a). Biochemical evidence for the presence of two $\alpha$-glucoside ABCtransport systems in the hyperthermophilic archaeon Pyrococcus furiosus. Archaea 1, 19-25.

Koning, S. M., Elferink, M. G. L., Konings, W. N. \& Driessen, A. J. M. (2001b). Cellobiose uptake in the hyperthermophilic archaeon Pyrococcus furiosus is mediated by an inducible, highaffinity ABC transporter. J Bacteriol 183, 4979-4984.

Nelson, K. E., Clayton, R. A., Gill, S. R. \& 26 other authors (1999). Evidence for lateral gene transfer between archaea and bacteria from genome sequence of Thermotoga maritima. Nature 399, 323-329.

Nelson, K. E., Eisen, J. A. \& Fraser, C. M. (2001). Genome of Thermotoga maritima MSB8. In Methods in Enzymology, Hyperthermophilic Enzymes, part A, pp. 169-180. Edited by
M. W. W. Adams \& R. M. Kelly. San Diego, CA: Academic Press.

Nesbo, C. L., L'Haridon, S., Stetter, K. O. \& Doolittle, W. F. (2001). Phylogenetic analyses of two 'archaeal' genes in Thermotoga maritima reveal multiple transfers between archaea and bacteria. Mol Biol Evol 18, 362-375.

Pace, N. R. (1997). A molecular view of microbial diversity and the biosphere. Science 276, 734-740.

Paulsen, I. T. (1999). Genomic comparisons of membrane transport systems (http://www.biology.ucsd.edu/ ipaulsen/transport/).

Paulsen, I. T., Nguyen, L., Sliwinski, M. K., Rabus, R. \& Saier, M. H., Jr (2000). Microbial genome analyses: comparative transport capabilities in eighteen prokaryotes. J Mol Biol 301, 75-100.

Richarme, G. \& Kepes, A. (1983). Study of binding protein-ligand interaction by ammonium sulfate-assisted adsorption on cellulose esters filters. Biochim Biophys Acta 742, 16-24.

Sambrook, J., Fritsch, E. F. \& Maniatis, T. (1989). Molecular Cloning: a Laboratory Manual, 2nd edn. Cold Spring Harbor, NY : Cold Spring Harbor Laboratory.

Wassenberg, D., Liebl, W. \& Jaenicke, R. (2000). Maltose-binding protein from the hyperthermophilic bacterium Thermotoga maritima: stability and binding properties. J Mol Biol 295, 279-288.

Xavier, K. B., Martins, L. O., Peist, R., Kossmann, M., Boos, W. \& Santos, H. (1996). High-affinity maltose/trehalose transport system in the hyperthermophilic archaeon Thermococcus litoralis. J Bacteriol 178, 4773-4777.

Received 3 June 2002; accepted 15 July 2002. 